\title{
Alternariol induces DNA polymerase $\beta$ expression through the PKA-CREB signaling pathway
}

\author{
JIMIN ZHAO*, KANGDONG LIU**, JING LU, JUNFEN MA, XIAOYAN ZHANG, YANAN JIANG, \\ HONGYAN YANG, GE JIN, GUOQIANG ZHAO, MINGYAO ZHAO and ZIMING DONG
}

Department of Pathophysiology, School of Basic Medical Sciences, Zhengzhou University, Zhengzhou 450001, P.R. China

Received November 28, 2011; Accepted January 30, 2012

DOI: 10.3892/ijo.2012.1398

\begin{abstract}
Alternariol ( $\mathrm{AOH})$ is a mycotoxin of Alternaria alternata and can cause DNA damage and gene mutations. Low-dose and long-term treatment with $\mathrm{AOH}$ has been linked with incidence of esophageal carcinoma. DNA polymerase $\beta(\operatorname{pol} \beta)$ is a key enzyme in DNA base excision repair (BER). When it is overexpressed or mutated in cells, DNA pol $\beta$ can cause genetic instability. Elevated DNA pol $\beta$ has also been reported in several human cancers. Here, we report that $\mathrm{AOH}$ at 2,10,20 $\mu \mathrm{M}$ induces DNA pol $\beta$ expression. In the process, protein kinase A (PKA) catalytic subunit activation, nuclear translocation and cAMP response element binding protein (CREB) phosphorylation are involved. $\mathrm{AOH}$ also increased $\mathrm{CREB}$ binding to the $\mathrm{AMP}$ response element (CRE) consensus motif, which is present in the DNA pol $\beta$ gene promoter. The PKA inhibitor H89 was able to block AOH-induced PKA-CREB activation, CREB DNA binding activity and decrease DNA pol $\beta$ expression. Our results suggest that $\mathrm{AOH}$ can upregulate DNA pol $\beta$ expression through the PKA-CREB signal transduction pathway.
\end{abstract}

\section{Introduction}

The genus Alternaria are wildly distributed in agricultural products such as wheat, tomatoes and apple juice $(1,2)$. According to their different structures, mycotoxins of alternaria are classified into three types: tetramic acid derivatives, dibenzopyrone derivatives and perylene derivatives $(2,3)$. Alternariol $(\mathrm{AOH})$ is one of the important secondary products, belonging to dibenzopyrone derivatives, which is widely investigated on different aspects. $\mathrm{AOH}$ can cause frameshift mutations using

Correspondence to: Dr Ziming Dong, Department of Pathophysiology, School of Basic Medical Sciences, Zhengzhou University, Zhengzhou 450001, P.R. China

E-mail: dongzm@zzu.edu.cn

*Contributed equally

Key words: alternariol, DNA polymerase $\beta$, protein kinase A, cAMP responds element binding protein, signaling pathway
Ames Salmonella strain TA97 (4). In cultured mammalian cells, $\mathrm{AOH}$ induced hypoxanthine-guanine phosphoribosyltransferase (HPRT) and thymidine kinase (TK) gene mutation (5). Our previous work also indicated AOH can cause DNA strands breaks (6). Squamous cell carcinoma of the fetal esophagus could be induced by $\mathrm{AOH}$, and exposure to low level of $\mathrm{AOH}$ was associated with esophageal cancer $(7,8)$.

Base excision repair (BER) is a process that recognize and repair DNA damage, which is caused by oxidant damage, and alkylation $(9,10)$. BER is responsible for genetic stability $(11,12)$. DNA polymerase beta $(\operatorname{pol} \beta)$ is a key enzyme responsible for BER (13). Pol $\beta$ is a $39-\mathrm{kDa}$ protein, which includes two domains, 8 and $31 \mathrm{kDa}$. The 8-kDa domain excises the 5-deoxyribose phosphate and the $31-\mathrm{kDa}$ domain catalyses nucleotidyl to fill the gap $(14,15)$. DNA pol $\beta$ exists at relatively low level and constant expression in normal somatic cells (16). Endogenous and exogenous factor-caused DNA damage can induce DNA $\operatorname{pol} \beta$ expression. Overexpression of $\operatorname{pol} \beta$ was found in various human cancers such as esophageal carcinoma, gastric carcinoma, ovarian cancer (17-19). However, the pathway involved in pol $\beta$ expression has not been fully investigated, and the role of pol $\beta$ in tumorigenesis is still puzzling.

In the present study, the pathway involved in $\mathrm{AOH}$ induced pol $\beta$ expression was investigated. We showed $\mathrm{AOH}$-induced PKA activation and CREB phosphorylation, which related to pol $\beta$ expression. Inhibition of PKA activity by H89 suppressed CREB phosphorylation and PKA-CREB-mediated pol $\beta$ expression. These results indicated $\mathrm{AOH}$ could induce pol $\beta$ expression via PKA-CREB signaling.

\section{Materials and methods}

Cell culture. NIH3T3 cells were cultured at $37^{\circ} \mathrm{C}\left(5 \% \mathrm{CO}_{2}\right)$ in RPMI-1640 with $10 \%$ fetal calf serum and $100 \mathrm{U} / \mathrm{ml}$ penicillin and $100 \mathrm{U} / \mathrm{ml}$ streptomycin.

Immunocytochemistry analysis. Cells were grown on glass coverslips in a 24-well plate and treated with drugs. The cells were fixed with $4 \%$ paraformaldehyde for $30 \mathrm{~min}$. Cells were incubated with $3 \% \mathrm{H}_{2} \mathrm{O}_{2}$ for $30 \mathrm{~min}$, and were blocked with normal rabbit serum for $30 \mathrm{~min}$ to reduce non-specific binding, then incubated with anti-p-PKA catalytic subunit (1:200, Santa Cruz), anti-p-CREB (1:50, Cell Signaling) or anti-pol $\beta$ antibody (1:200, Santa Cruz) overnight at $4^{\circ} \mathrm{C}$. After 
rinsing with PBS, the cells were incubated with biotin-labeled secondary antibody for $1 \mathrm{~h}$ at room temperature. Finally, the cells were stained with diaminobenzidine (DAB).

Immunofluorescence analysis. The steps were similar to immunocytochemistry procedures. FITC-conjugated goat anti-rabbit or donkey anti-goat $\operatorname{IgG}$ was used as secondary antibody and incubated with cells for 30 min without light. The cells were observed with a fluorescence microscope.

Western blotting. Cell lysate $(50 \mu \mathrm{g})$ was separated on a $10 \%$ SDS-polyacrylamide gel and transferred to PVDF membrane. After blocking with 5\% non-fat dried milk for $30 \mathrm{~min}$, membrane was incubated with respectively primary antibody at $4^{\circ} \mathrm{C}$ overnight (1:200 dilution for anti-PKA, 1:1,000 for anti-p-CREB, 1:200 for anti-pol $\beta, 1: 1,000$ for anti-CREB). HRP-IgG secondary antibody was used for $2 \mathrm{~h}$ at room temperature. Protein bands were visualized by an enhanced chemiluminescence detection kit (ECL, Pierce). The bands were subjected to densitometry for quantitation using Bio-Rad Quantity One software.

Electrophoretic mobility shift assay (EMSA). Nuclear extracts were prepared according to the protocol of nucleoprotein extraction kit (Beyotime). The sequence of the oligonucleotide of CRE was: 5'-TCGATTGGCTGACGTCAGAGAGAG-3'. As a control, the mutational CRE sequence: 5'-TCGATTGGC ACTCGTCAGAGAGAG-3' was employed. These oligonucleotides were labeled according to the protocol of the Biotin 3'-end DNA Labeling Kit (Beyotime). The single-stranded oligonucleotide probes were annealed to be double-strands. EMSA was performed using the LightShift Chemiluminescent EMSA Kit (Beyotime). The specificity of binding was examined by competition with a 100 -fold molar excess of unlabeled double stranded oligonucleotide added to the mixture. For supershift assays, the nuclear extract was incubated for $20 \mathrm{~min}$ at room temperature with labeled probe and antibodies against phosphorylated CREB (Ser133) (Cell Signaling). The complexes of oligonucleotide probes and nuclear protein were separated from the unbound probes by electrophoresis with $6 \%$ polyacrylamide gels. A transfer of the complex and free probes from the polyacrylamide gel onto the nylon membrane was performed by the semi-dry transfer method. The membranes were visualized with ECL.

Statistical analyses. All results are presented as mean \pm SEM, statistical analysis was performed by ANOVA in SPSS 11.0 software. $\mathrm{P}<0.05$ was considered to indicate statistical significance.

\section{Results}

AOH-induced DNA pol $\beta$ expression. To investigate whether $\mathrm{AOH}$ can induce pol $\beta$ expression or not, NIH3T3 cells were treated with $\mathrm{AOH}$. Immunocytochemistry assay and Western blotting was performed to determine pol $\beta$ protein level after different dose of $\mathrm{AOH}$ treatment. In immunocytochemistry assay, brown coloration was obviously seen in cell nucleus of 10 and $20 \mu \mathrm{M}$ AOH-treated groups (Fig. 1A). Western blotting results exhibited that the protein level of pol $\beta$ increased in a dose-dependent manner with AOH treatment (Fig. 1B).
A

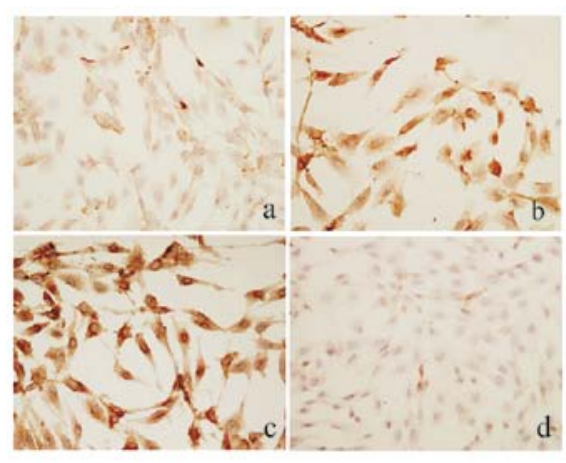

B

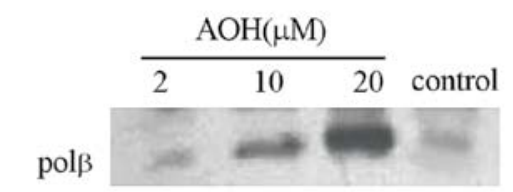

$\beta$-actin $1+2=0+2=0$

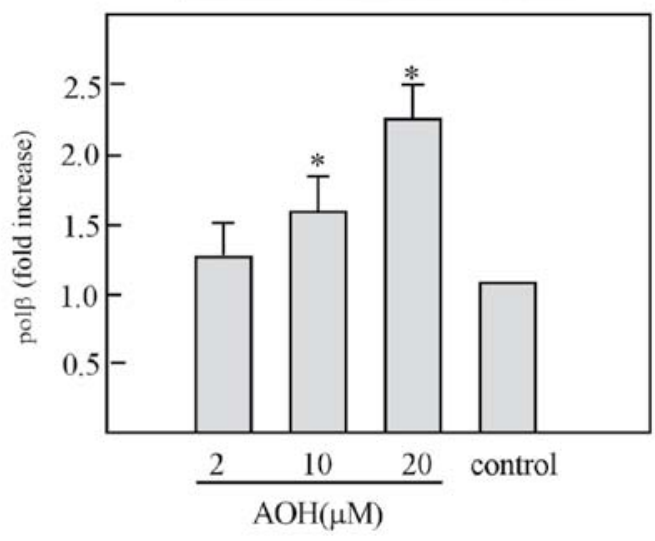

Figure 1. AOH induces DNA pol $\beta$ expression. NIH3T3 cells were treated with $2,10,20 \mu \mathrm{M} \mathrm{AOH}$ and DMSO respectively for $16 \mathrm{~h}$. (A) Immunocytochemistry analysis showed pol $\beta$ expression in 2, $10,20 \mu \mathrm{M}$ AOH and control group: (a) $2 \mu \mathrm{M} \mathrm{AOH}$; (b) $10 \mu \mathrm{M} \mathrm{AOH}$; (c) $20 \mu \mathrm{M} \mathrm{AOH;} \mathrm{(d)} \mathrm{control.} \mathrm{(B)} \mathrm{Western}$ blotting results showed pol $\beta$ expression increased after $\mathrm{AOH}$ treatment. Data are shown as means \pm SD of values from triplicate experiments. "Significant $(\mathrm{P}<0.05)$ change in expression compared to DMSO treatment.

AOH-induced activation of PKA and nuclear translocation. PKA activation was induced by $2,10,20 \mu \mathrm{M} \mathrm{AOH}$ for $1 \mathrm{~h}$ in immunocytochemistry experiments, brown coloration was obviously seen in cell nucleus of the 10 and $20 \mu \mathrm{M} \mathrm{AOH}$-treated groups (Fig. 2A). Immunofluorescence analysis also indicated the nuclear translocation of activated PKA increased after $20 \mu \mathrm{M} \mathrm{AOH}$ treatment compared with control group (Fig. 2E).

Western blotting was used to determine the level of PKA activation after $\mathrm{AOH}$ treatment at different time-point. Results showed the activation of PKA increased in a dose-dependent manner (Fig. 2B). The level of PKA activation was the highest when the NIH3T3 cells were treated with $20 \mu \mathrm{M}$ AOH at 60 min (Fig. 2C). H89, an inhibitor of PKA, can effectively block PKA activation (20). To confirm whether $\mathrm{AOH}$ induced PKA activation, we pretreated the NIH3T3 cells with $10 \mu \mathrm{M}$ $\mathrm{H} 89$ for $1 \mathrm{~h}$, and then treated the cells with $20 \mu \mathrm{M} \mathrm{AOH}$. Immunofluorescence analysis showed a significant decrease of PKA actvation in H89 pretreatment group compared with the AOH-treated group (Fig. 2E). Similar results were observed in 
A
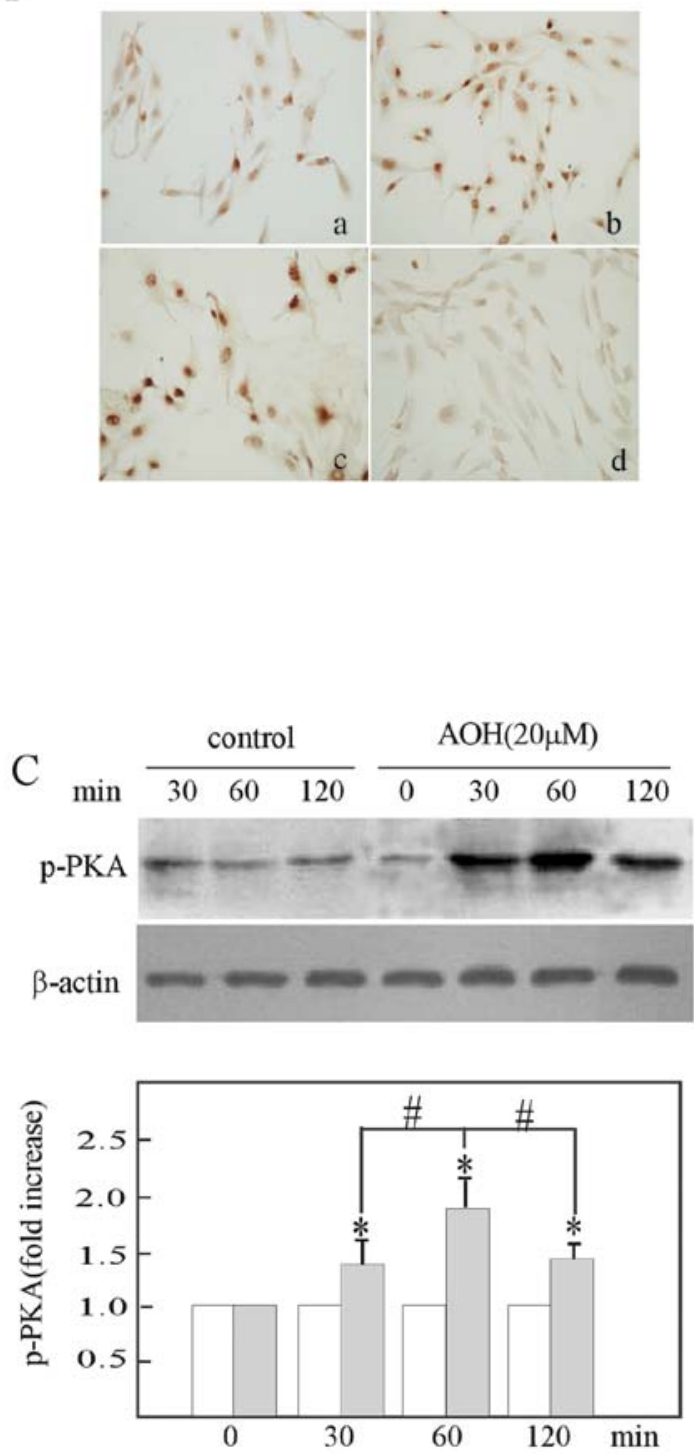

$\mathrm{E}$

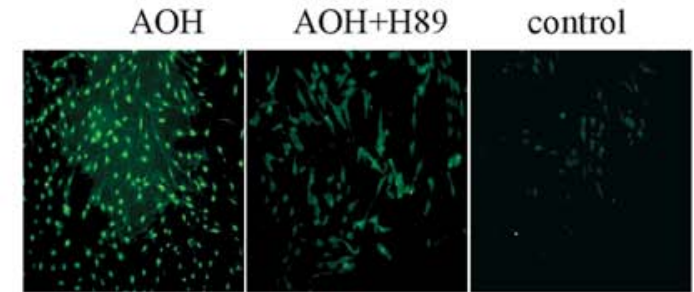

B

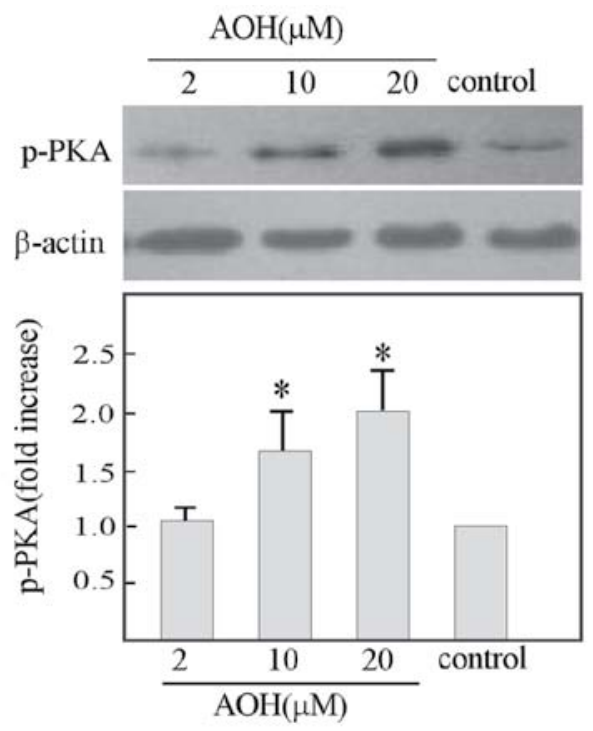

$\mathrm{D}$
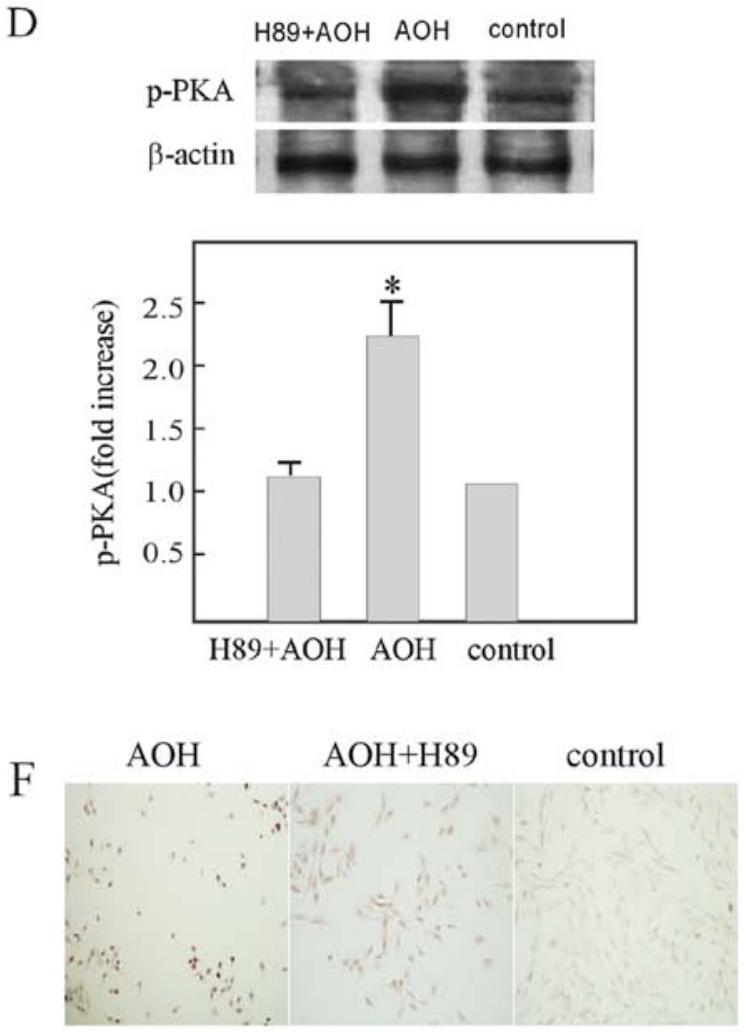

Figure 2. AOH-induced PKA catalytic subunit activation and translocation. NIH3T3 cells were treated with indicated dose of AOH for $1 \mathrm{~h}$. The levels of phosphorylated PKA catalytic subunit were visualized by immunocytochemistry analysis (magnification $\mathrm{x} 400$ ) (A) and Western blotting (B). The cells were treated with AOH for the indicated time, and the levels of phosphorylated PKA catalytic subunit were measured by Western blotting (C). Cells were pretreated with $\mathrm{H} 89(10 \mu \mathrm{M}) 1 \mathrm{~h}$ prior to $20 \mu \mathrm{M} \mathrm{AOH}$ exposure. The results indicated by Western blotting (D) immunofluorescence analysis (magnification x200) (E) and immunocytochemistry analysis (magnification $\mathrm{x} 200)(\mathrm{F})$. Data are shown as means \pm SD of values from triplicate experiments. "Significant $(\mathrm{P}<0.05)$ change in expression compared to DMSO treated control. "Significant $(\mathrm{P}<0.05)$ change in expression compared to the group of AOH treatment for 60 min.

Western blotting (Fig. 2D) and immunocytochemistry analysis (Fig. 2F).

AOH-induced activation of CREB. PKA is an important regulator of CREB activity. PKA can phosphorylate CREB at Ser133 and activate it fully (21). To determine whether AOH-mediated PKA activation can phosphorylate CREB in NIH3T3 cells, we investigated phosphorylation status of CREB on Ser133. Immunocytochemistry analysis showed CREB phosphorylation increased in 10 and $20 \mu \mathrm{M}$ AOH-treated groups (Fig. 3A). Western blot analysis also demonstrated that $\mathrm{AOH}$ induced CREB phosphorylation in a dose-dependent manner (Fig. 3B and $\mathrm{C}$ ). The phosphorylation peaked at $2 \mathrm{~h}$ after $20 \mu \mathrm{M} \mathrm{AOH}$ treatment (Fig. 3C). The phosphorylation level decreased after 
A

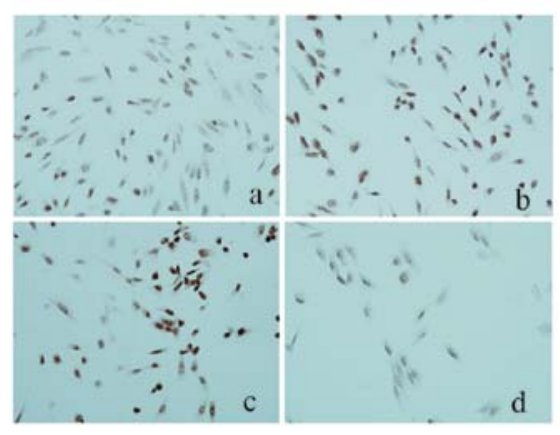

$\mathrm{C}$
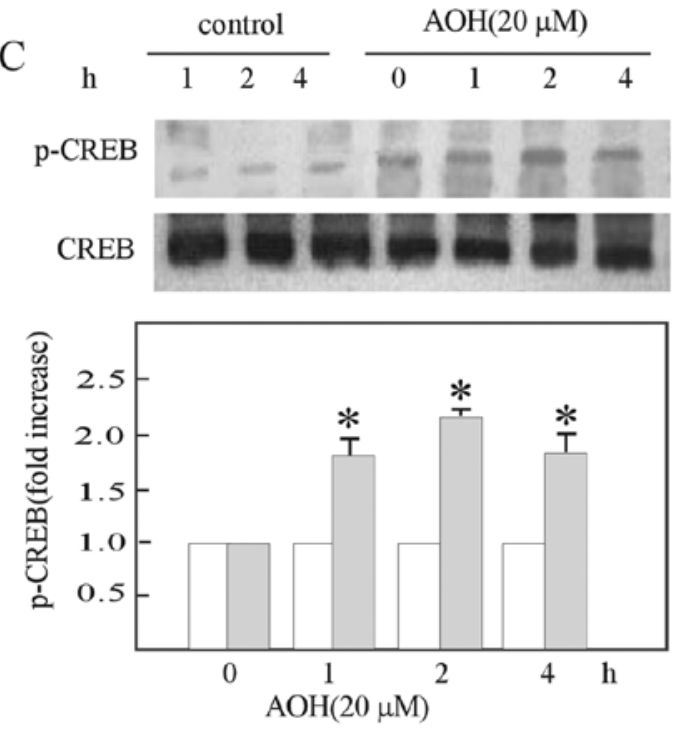

$\mathrm{E}$

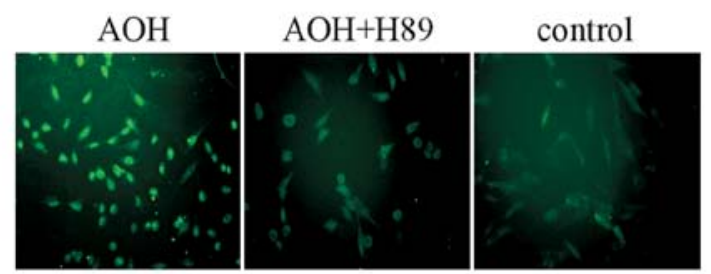

F

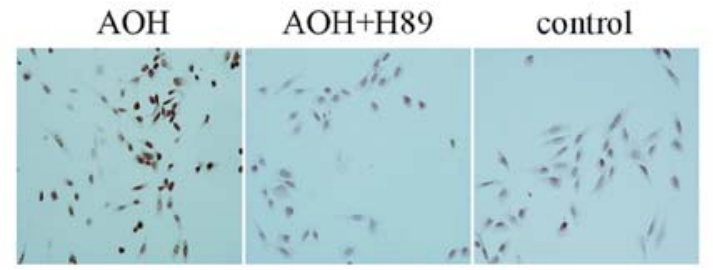

B
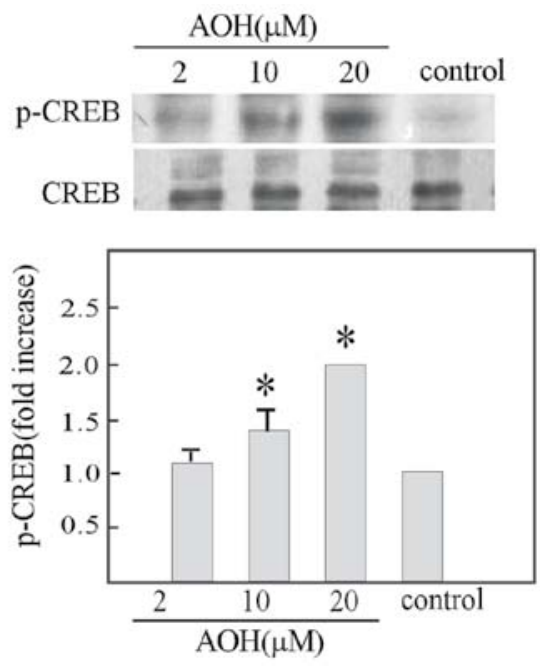

D $\mathrm{H} 89+\mathrm{AOH} \mathrm{AOH}$ control
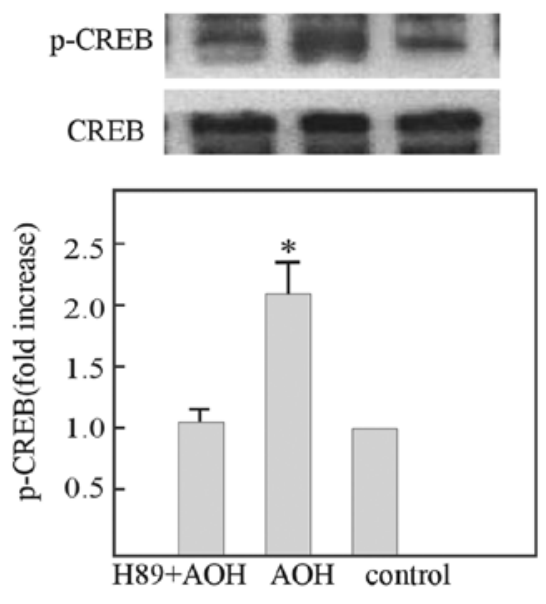

G

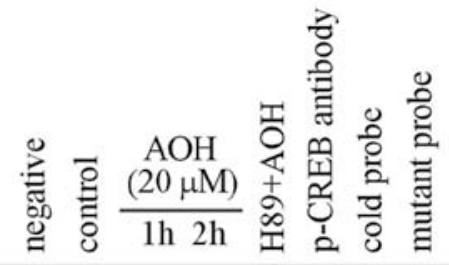

compound

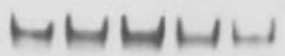

free probe

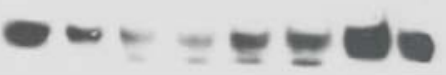

Figure 3. AOH-induced phosphorylation of CREB. NIH3T3 cells were treated with indicated dose of AOH for $2 \mathrm{~h}$. The levels of phosphorylated CREB were visualized by immunocytochemistry analysis (magnification x100) (A) and Western blotting (B). The cells were treated with AOH for 1,2 and $4 \mathrm{~h}$ and the levels of phosphorylated CREB were measured by Western blotting (C). Cells were pretreated with $\mathrm{H} 89(10 \mu \mathrm{M})$ for $1 \mathrm{~h}$ prior to $20 \mu \mathrm{M}$ AOH exposure. The results were measured by Western blotting (D), immunofluorescence analysis (magnification x200) (E) and immunocytochemistry analysis (magnification x200) (F). The p-CREB DNA binding activity was detected by EMSA $(\mathrm{G})$. Data are shown as means \pm SD of values from triplicate experiments. "Significant $(\mathrm{P}<0.05)$ change in expression compared to DMSO treated control.

H89 $(10 \mu \mathrm{M})$ treatment (Fig. 3D, E and F). These results indicated that $\mathrm{AOH}$ stimulated PKA activation followed by CREB phosphorylation.
Phosphorylation of CREB at Ser133 closely related with its DNA binding activity. Next, we checked whether AOH treatment can increase CREB DNA binding activity in NIH3T3 
A

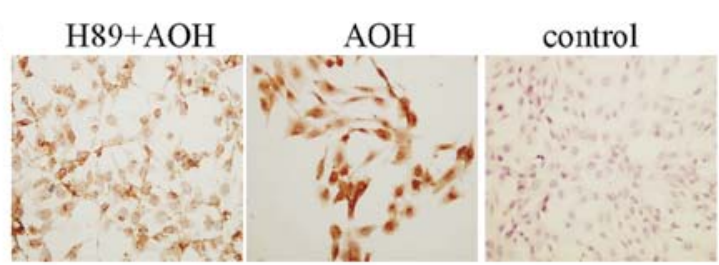

B

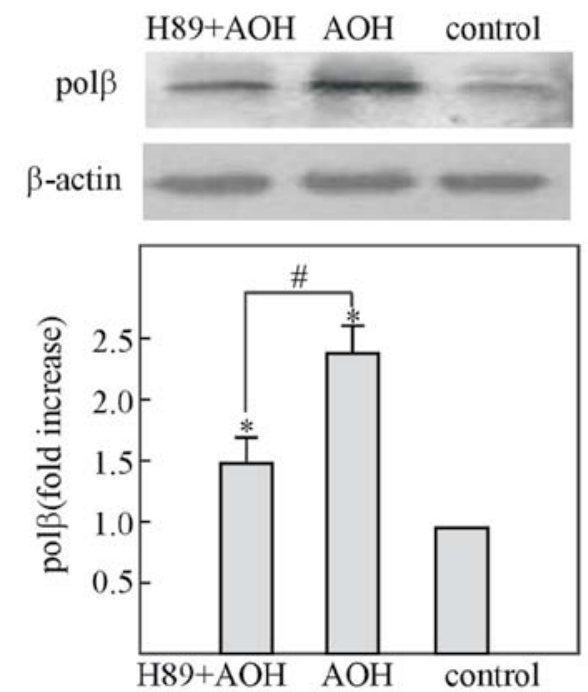

Figure 4. H89 inhibited the expression of DNA pol $\beta$. NIH3T3 cells were treated with $\mathrm{H} 89$ prior to $\mathrm{AOH}$ treatment. DNA pol $\beta$ expression was detected by immunocytochemistry analysis (magnification x400) (A) and Western blotting (B). Data are shown as means $\pm \mathrm{SD}$ of values from triplicate experiments. "Significant $(\mathrm{P}<0.05)$ change in expression compared to DMSO treated control. " Significant $(\mathrm{P}<0.05)$ change in expression compared to H89 pretreatment group.

cells. Cells were treated with $\mathrm{AOH}(20 \mu \mathrm{M})$ for various time periods and then the activity of CREB was detected by EMSA. The result indicated $\mathrm{AOH}$ treatment at 1 and $2 \mathrm{~h}$, respectively, increased CREB DNA binding activity compared to DMSOtreated control. CREB DNA binding activity was partly inhibited by pretreatment with H89 (Fig. 3G). These results demonstrated phosphorylated CREB stimulated by $\mathrm{AOH}$ strongly binded to cAMP response elements containing the 5'-TGACGTCA-3' consensus motif. The specificity of binding was examined by competition with the unlabeled probes (cold probes) and supershift assays.

$A O H$ up-regulated pol $\beta$ expression via the activated PKA-CREB pathway in NIH3T3 cells. AOH can cause DNA damage and stimulate DNA pol $\beta$ expression. To check whether this procedure is through PKA-CREB signaling transduction pathway NIH3T3 cells were treated with DMSO, AOH $(20 \mu \mathrm{M})$ and $\mathrm{AOH}$ together with $\mathrm{H} 89(20 \mu \mathrm{M} \mathrm{AOH}$ and $10 \mu \mathrm{M}$ $\mathrm{H} 89$ ) for $16 \mathrm{~h}$. Western blot and immunocytochemistry analysis both indicated that $\mathrm{AOH}$ led to a significant increase in pol $\beta$ protein level and $\mathrm{H} 89$ treatment inhibited $\mathrm{AOH}$-induced pol $\beta$ protein level (Fig. 4). The results were consistent with PKA and CREB activation.

\section{Discussion}

In mammalian cells, DNA damage is an important event which arouses cell stress reaction. DNA damage repair systems can be initiated by DNA damage. Base excision repair (BER) is a process that recognizes and repairs damaged or modified bases, including oxidative base damage, multiple forms of alkylation damage and apurinic/apyrimidinic (AP) sites formed by the spontaneous loss of bases $(22,23)$. DNA pol $\beta$ is a nuclear enzyme involved in the base excision and single-stranded DNA break repair pathways and long patch base excision repair $(24,25)$. Studies have indicated DNA pol $\beta$ mutation in esophageal, colorectal and prostrate cancer (26-28). DNA pol $\beta$ overexpression was also found in various tumors indicating that DNA pol $\beta$ is closely related with tumorigenesis.

$\mathrm{AOH}$ was found closely related to esophageal tumorigenesis in our recent study after exposure of NIH3T3 cells to $10 \mu \mathrm{M}$ $\mathrm{AOH}(6)$. The data demonstrated that $\mathrm{AOH}$ caused tumorigenesis probably related to DNA damage and repair system. In this study, we found that pol $\beta$ expression was increased after $\mathrm{AOH}$ treatment (Fig. 1). These results might indicate that overexpression of pol $\beta$ participated in the $\mathrm{AOH}$-induced DNA damage repair.

Various signal transduction pathways are involed in tumorigenesis, including MAPK, PI3K/Akt, Notch, PKA-CREB pathway. In PKA lacking cells MNNG failed to activate the pol $\beta$ promoter (29). PKA comprises of two catalytic (C) subunits and two regulatory (R) subunits (30). The activity of the $\mathrm{C}$ subunit is regulated by a set of four different regulatory $R$ subunit isoforms. When $\mathrm{C}$ subunit is activated, it separates from $\mathrm{R}$ subunits and translocates into nucleus (30). To explore the role of PKA activation in $\mathrm{AOH}-$ induced pol $\beta$ expression, we detected PKA $\mathrm{C}$ subunit activation after $\mathrm{AOH}$ treatment. The results showed AOH initiated PKA C subunit activation and made its $C$ subunit to translocate to the nucleous (Fig. 2A and E). Moreover, PKA inhibitor $\mathrm{H} 89$ could inhibit $\mathrm{AOH}-m e d i a t e d \mathrm{PKA}$ activation and the nuclear translocation (Fig. 2E and F).

PKA have various downstream targets involved in different pathways. CREB is an important target of PKA. CREB is an important transcription factor which include a basic region leucine zipper (bZIP). CREB become an activator in phosphorylation state by PKA. Phosphorylated CREB binds via its bZIP domain as a dimer to cAMP response elements (CREs) containing the 5'-TGACGTCA-3' consensus motif $(31,32)$. To identify the function of PKA-CREB signaling pathway in pol $\beta$ expression, we checked the effect of AOH on CREB phosphorylation. AOH can induce CREB phosphorylation at Ser133, the peak of CREB phosphorylation emerged later than the peak of PKA after AOH treatment. In addition, PKA inhibitor H89 blocked CREB phosphorylation and inhibited expression of pol $\beta$. To investigate CREB-CRE binding activity when exposured to $\mathrm{AOH}$, we conducted EMSA. The result indicated that $\mathrm{AOH}$ strongly rendered the binding activity of CREB-CRE. These data showed that $\mathrm{p}$-CREB was involved in $\mathrm{AOH}$-induced DNA pol $\beta$ expression.

The sequence of DNA pol $\beta$ core promoter has three GC boxes and the decanucleotide palindromic sequence GTGACGTCAC at positions -49 to -40 (33). The element is similar to the ATF/CREB transcription factor-binding site. The transcriptional activation of pol $\beta$ promoter is exhibited strongly by DNA damaging agent MNNG treatment of CHO cells $(33,34)$. Mutated pol $\beta$ promotor fusion genes lacking the element failed to bind protein at this site and failed to respond to MNNG treatment of cells (29). It was shown that the Ser133 
phosphorylated CRE binding protein (CREB) was higher versus control in vero cells after 60 min of MNNG treatment $(35,36)$. The results suggested MNNG-induced pol $\beta$ expression might be mediated by PKA-CREB signaling pathway. In the present study, we examined the effects of AOH on PKA activation, CREB phosphorylation and pol $\beta$ expression. AOH can stimulate PKA activation, CREB phosphorylation and increase pol $\beta$ expression. PKA inhibitors can decrease CREB activation and inhibit DNA pol $\beta$ expression.

In conclusion, these data suggest $\mathrm{AOH}$ induced DNA pol $\beta$ expression through PKA-CREB signaling pathway. This procedure probably involved $\mathrm{AOH}$ induced tumorigenesis.

\section{Acknowledgements}

This work was supported by the National Basic Research Program of China (No. 2012CB933300) and the natural Science Foundation of the Henan province of China (No. 2011A310013, No. 2011A310009, No. 104200510009 and No. 112106000039).

\section{References}

1. Scott PM: Analysis of agricultural commodities and foods for Alternaria mycotoxins. J AOAC Int 84: 1809-1817, 2001.

2. Patriarca A, Azcarate MP, Terminiello L and Fernandez Pinto V: Mycotoxin production by Alternaria strains isolated from Argentinean wheat. Int J Food Microbiol 119: 219-222, 2007.

3. Li FQ, Toyazaki N and Yoshizawa T: Production of alternaria mycotoxins by Alternaria alternata isolated from weather-damaged wheat. J Food Prot 64: 567-571, 2001.

4. Schrader TJ, Cherry W, Soper K, Langlois I and Vijay HM: Examination of Alternaria alternata mutagenicity and effects of nitrosylation using the Ames Salmonella test. Teratog Carcinog Mutagen 21: 261-274, 2001.

5. Brugger EM, Wagner J, Schumacher DM, et al: Mutagenicity of the mycotoxin alternariol in cultured mammalian cells. Toxicol Lett 164: 221-230, 2006.

6. Zhao J, Ma J, Zhao J and Yang H: [Acute cytotoxicity of alternariol on NIH/3T3 cells]. J Hygiene Res 38: 133-135, 2009.

7. Liu GT, Qian YZ, Zhang P, Dong WH, Qi YM and Guo HT: Etiological role of Alternaria alternata in human esophageal cancer. Chinese Med J 105: 394-400, 1992.

8. Liu GT, Qian YZ, Zhang P, Dong ZM, Shi ZY, Zhen YZ, Miao J and $\mathrm{Xu}$ YM: Relationships between Alternaria alternata and oesophageal cancer. IARC Sci Publ 105: 258-262, 1991.

9. Allinson SL, Dianova II and Dianov GL: DNA polymerase beta is the major dRP lyase involved in repair of oxidative base lesions in DNA by mammalian cell extracts. EMBO J 20: 6919-6926, 2001.

10. David SS, O'Shea VL and Kundu S: Base-excision repair of oxidative DNA damage. Nature 447: 941-950, 2007.

11. Chan KK, Zhang QM and Dianov GL: Base excision repair fidelity in normal and cancer cells. Mutagenesis 21: 173-178, 2006.

12. Kidane D, Dalal S, Keh A, Liu Y, Zelterman D and Sweasy JB: DNA polymerase beta is critical for genomic stability of sperm cells. DNA Repair 10: 390-397, 2011.

13. Sobol RW, Horton JK, Kuhn R, et al: Requirement of mammalian DNA polymerase-beta in base-excision repair. Nature 379: 183-186, 1996.

14. Matsumoto Y and Kim K: Excision of deoxyribose phosphate residues by DNA polymerase beta during DNA repair. Science 269: 699-702, 1995.

15. Singhal RK and Wilson SH: Short gap-filling synthesis by DNA polymerase beta is processive. J Biol Chem 268: 15906-15911, 1993.

16. Zmudzka BZ,Fornace A, Collins J and Wilson SH: Characterization of DNA polymerase beta mRNA: cell-cycle and growth response in cultured human cells. Nucleic Acids Res 16: 9587-9596, 1988.
17. Dong ZM, Zheng NG, Wu JL, Li SK and Wang YL: Difference in expression level and localization of DNA polymerase beta among human esophageal cancer focus, adjacent and corresponding normal tissues. Dis Esophagus 19: 172-176, 2006.

18. Tan XH, Zhao M, Pan KF, et al: Frequent mutation related with overexpression of DNA polymerase beta in primary tumors and precancerous lesions of human stomach. Cancer Lett 220: 101-114, 2005.

19. Albertella MR, Lau A and O'Connor MJ: The overexpression of specialized DNA polymerases in cancer. DNA Repair 4: 583-593, 2005.

20. Chijiwa T, Mishima A, Hagiwara M, et al: Inhibition of forskolininduced neurite outgrowth and protein phosphorylation by a newly synthesized selective inhibitor of cyclic AMP-dependent protein kinase, $\mathrm{N}$-[2-(p-bromocinnamylamino)ethyl]-5-isoquinoline sulfoamide (H-89), of PC12D pheochromocytoma cells. J Biol Chem 265: 5267-5272, 1990.

21. Sands WA and Palmer TM: Regulating gene transcription in response to cyclic AMP elevation. Cell Signal 20: 460-466, 2008.

22. Pascucci B, Russo MT, Crescenzi M, Bignami M and Dogliotti E: The accumulation of MMS-induced single strand breaks in G1 phase is recombinogenic in DNA polymerase beta defective mammalian cells. Nucleic Acids Res 33: 280-288, 2005.

23. Sung JS and Demple B: Roles of base excision repair subpathways in correcting oxidized abasic sites in DNA. FEBS J 273: 1620-1629, 2006.

24. Fortini P,Pascucci B, Belisario F and Dogliotti E: DNA polymerase beta is required for efficient DNA strand break repair induced by methyl methanesulfonate but not by hydrogen peroxide. Nucleic Acids Res 28: 3040-3046, 2000.

25. Asagoshi K, Liu Y, Masaoka A, et al: DNA polymerase betadependent long patch base excision repair in living cells. DNA Repair 9: 109-119, 2010.

26. Zhao GQ, Wang T, Zhao Q, Yang HY, Tan XH and Dong ZM: Mutation of DNA polymerase beta in esophageal carcinoma of different regions. World J Gastroenterol 11: 4618-4622, 2005.

27. Wang L, Patel U, Ghosh L and Banerjee S: DNA polymerase beta mutations in human colorectal cancer. Cancer Res 52: 4824-4827, 1992.

28. Dobashi Y, Shuin T, Tsuruga H, Uemura H, Torigoe $S$ and Kubota Y: DNA polymerase beta gene mutation in human prostate cancer. Cancer Res 54: 2827-2829, 1994.

29. Englander EW and Wilson SH: DNA damage response of cloned DNA beta-polymerase promoter is blocked in mutant cell lines deficient in protein kinase A. Nucleic Acids Res 20: 5527-5531, 1992.

30. Kim C, Vigil D, Anand G and Taylor SS: Structure and dynamics of PKA signaling proteins. Eur J Cell Biol 85: 651-654, 2006.

31. Shaywitz AJ and Greenberg ME: CREB: a stimulus-induced transcription factor activated by a diverse array of extracellular signals. Annu Rev Biochem 68: 821-861, 1999.

32. Lonze BE and Ginty DD: Function and regulation of CREB family transcription factors in the nervous system. Neuron 35: 605-623, 2002.

33. Widen SG and Wilson SH: Mammalian beta-polymerase promoter: large-scale purification and properties of ATF/CREB palindrome binding protein from bovine testes. Biochemistry 30: 6296-6305, 1991.

34. He F, Yang XP, Srivastava DK and Wilson SH: DNA polymerase beta gene expression: the promoter activator CREB-1 is upregulated in Chinese hamster ovary cells by DNA alkylating agent-induced stress. Biol Chem 384: 19-23, 2003.

35. Wang G, Yu Y, Chen X and Xie H: Low concentration N-methylN'-nitro-N-nitrosoguanidine activates DNA polymerase-beta expression via cyclic-AMP-protein kinase A-cAMP response element binding protein pathway. Mutat Res 478: 177-184, 2001.

36. Wang Z, Wang G, Yang J, Guo L and Yu Y: Activation of protein kinase $\mathrm{A}$ and clustering of cell surface receptors by $\mathrm{N}$-methyl$\mathrm{N}$-nitro-N-nitrosoguanidine are independent of genomic DNA damage. Mutat Res 528: 29-36, 2003. 